\title{
Low physical capacity among adolescents in practical education
}

\author{
Sollerhed A-C, Ejlertsson G. Low physical capacity among adolescents in \\ practical education. \\ Scand J Med Sci Sports 1999: 9: 249-256. (C) Munksgaard, 1999 \\ The aim of this study was to obtain better knowledge about teenagers' \\ physical capacity and physical activity. The study group consisted of 301 \\ students in upper secondary school, 191 students in practical education \\ ( 74 girls and 117 boys) and 110 students in theoretical education ( 57 girls \\ and 53 boys). The adolescents were 16-19 years old and lived in southern \\ Sweden. The study comprised three parts: a questionnaire, seven physical \\ tests (one test to predict maximal oxygen uptake, three strength tests, two \\ flexibility tests and one balance test) and information on each pupil's \\ grades. Pupils in practical education for occupations like industrial- and \\ building workers, mechanics, assistant nurses and hairdressers, all of \\ which are occupations involving physical effort, had lower physical ca- \\ pacity than pupils in theoretical education among both girls and boys. A \\ correlation was found between physical capacity and grades.
}

\author{
A.-C. Sollerhed ${ }^{1}$, G. Ejlertsson ${ }^{2}$ \\ ${ }^{1}$ Department of Humanity and Social Sciences \\ 2Department of Health Sciences, \\ Kristianstad University, Kristianstad, Sweden \\ Key words: physical education; physical activity: \\ physical capacity; adolescence; physical tests; \\ questionnaire \\ Ann-Christin Sollerhed, Department of Humanity \\ and Social Sciences, Kristianstad University, \\ 29188 Kristianstad, Sweden \\ Accepted for publication 4 May 1999
}

Regular physical activity is generally viewed as having a favourable influence on the growth, biological maturation and physical fitness of children and young people (1). Children's habitual physical activity is associated with health-related fitness, including cardiovascular endurance and muscular strength and endurance $(1,2)$. Physical activity improves the creation of networks of nerve cells, which is the essence of learning (3). Physical activity in adolescence (defined as ages 11 to 21 ) reduces the risk of obesity (4), increases the density of skeletal bones (5), and improves psychological health and mood (6).

In modern society many children are physically inactive during their leisure time (7-10). It has been well documented that watching television is a major pastime for many people, especially children and adolescents (11). The average 10-17-year-old American spends $21 \mathrm{~h}$ per week viewing television (12). The use of computers has advanced during the 1990s, and one result is that more time spent at the computer will reduce time available for physical activity (13).

In schools in Europe the time for lessons in physical education has been cut down. In Sweden the time allocated for physical education is about an hour a week. That gives Sweden position number 24 among the 25 countries in a recent study (14).

As many children and adolescents are inactive and sedentary both during leisure time and in school, they are at risk of becoming sedentary adults (10), and we can expect many frail adults in working life in the future. To the best of our knowledge, there is no study concerning physical capacity as a predictor for musculoskeletel diseases in young adults starting their working life.

Work-related musculoskeletal diseases account for a large number of workers' compensation days and disability in numerous industrial countries (15-17). Besides causing individual suffering, musculoskeletal disorders result in heavy costs for companies and for governments. Although it is clear that heavy physical work has diminished, the amount of disability owing to musculoskeletal diseases was still increasing in the last decade $(15,16)$. In Sweden early retirement pensions increased from $33 \%$ to $49 \%$ in the years 1985 to 1990 , the most common cause being musculoskeletal diseases (18). Epidemiological studies in unselected populations have demonstrated prevalence rates of around $50 \%$ for musculoskeletal pain (19). Musculoskeletal diseases are of multifactorial origin. There is a relationship between musculoskeletal diseases and physical load during work. Individual risk factors are age, smoking, relative muscle strength and physical fitness (17). Weak trunk muscles and reduced flexibility of the back were found among workers with lower back trouble $(20,21)$.

There is a great deal of scientific evidence linking 


\section{Ann-Christin Sollerhed}

\section{Sollerhed \& Ejlertsson}

regular physical activity to a wide array of physical and mental benefits (22), and regular physical activity is essential for optimal functioning of the human body (23). A low level of physical fitness is an important risk factor for all-cause mortality (24). Physical activity has been suggested to protect against the development of several kinds of diseases among adults (25-32). The effects on young people are just beginning to be understood, but it is clear that physical activity has beneficial effects on many bodily systems (33). Coronary heart diseases, osteoporosis and hypertension in adulthood have antecedents during childhood and adolescence $(5,34-36)$. Boys and girls who are more physically active and more fit during late childhood and adolescence are more likely to be active as adults (1)

The purpose of this study was to obtain better knowledge about teenagers' physical capacity and physical activity. A comparison was made between pupils in practical and theoretical education, bearing in mind that the pupils in the future will be employees in different occupations requiring components of health-related fitness.

\section{Material and methods}

\section{Subjects}

The study comprised 301 pupils, aged 16-19 years, and was performed in 1996 in Kristianstad, a town in southern Sweden with a population of about 70000 inhabitants. Pupils attending different educational programmes in upper secondary school in Kristianstad came from both the city of Kristianstad and the rural surroundings. The upper secondary school in Sweden consists of 16 different educational programmes, 14 practical and two theoretical. Approximately $98 \%$ of all teenagers in Sweden attend these programmes, which all last for three years. Pupils in practical programmes receive vocational education for a specific occupation, both in school and in trainee jobs. They also receive education in traditional school subjects. The theoretical programmes are preparatory for academic studies at university.

The six practical programmes in this study were selected because they lead to jobs involving physical effort: mechanics, building workers, industrial workers, butchers, hairdressers and assistant nurses. The theoretical programmes were in either science or civics. In all, the pupils in the study came from 16 different classes, two classes in every programme, one in the first year and one in the third. In these 16 classes the total number of pupils was 355 , of which 301 pupils $(85 \%)$ were present at school on the test day (Table 1). In all analyses of the physical tests the first and third form were put together in one group, as there were no significant differences between their results, except in one case. Among girls, there was a difference in the jump test: girls in the first form jumped higher than girls in the third form.

\section{Methods and definitions}

The study comprised three parts, a questionnaire, physical tests and information on each pupil's grades.

The questionnaire included questions about exercise habits in leisure time and opinions about physical education at school. The questionnaire was tested in a pilot study, and adjusted before use. The students answered the questionnaire in school before doing the physical tests.

Definitions of concepts in the questionnaire:

Self-reported leisure-time exercise: exercise done in spare time. The item in the questionnaire was: "How often do you exercise physically in your leisure time so you get out of breath and sweaty?" Three groups were formed out of the seven response categories: regularly three times or more per week, regularly once or twice a week, and the last group - a few times per month but not regularly, a few times per year or never.

Enough exercise in school: answers to the question "Do you think you get enough exercise during lessons in physical education in school to be in good condition?" with the four response categories: "yes completely, yes mostly, no mostly not, or no not at all".

Valuation of time for physical education: answers to the question "What is your opinion about the time allocated for physical education in your year in

Table 1. Number of pupils in the study, pupils present at school on the test day, responders to questionnaire, and participants in the physical tests among girls and boys in practical and theoretical education

\begin{tabular}{|c|c|c|c|c|}
\hline & \multicolumn{2}{|c|}{ Girls } & \multicolumn{2}{|c|}{ Boys } \\
\hline & $\begin{array}{l}\text { Practical } \\
\text { education }\end{array}$ & $\begin{array}{l}\text { Theoretical } \\
\text { education }\end{array}$ & $\begin{array}{l}\text { Practical } \\
\text { education }\end{array}$ & $\begin{array}{l}\text { Theoretical } \\
\text { education }\end{array}$ \\
\hline Study groups & 88 & 59 & 148 & 60 \\
\hline Pupils present at school & 74 & 57 & 117 & 53 \\
\hline Responders to questionnaire & 74 & 57 & 117 & 53 \\
\hline Participants in physical tests & 73 & 54 & 115 & 51 \\
\hline Participants in all seven tests & 66 & 47 & 110 & 47 \\
\hline
\end{tabular}


Physical capacity among adolescents

school?" with the five response categories: "far too much time, somewhat too much time, just enough time, somewhat too little time, far too little time".

Presumed future physical demands: the item in the questionnaire was "Which physical demands do you think will be important in your future work?" The options were: aerobic fitness, strength, flexibility, balance, coordination, fast reactions, precision.

Physical capacity was measured by seven physical tests, containing predicted maximal oxygen uptake (MOU), muscular strength in arms, abdomen and legs, flexibility and balance. These seven tests were chosen because they were possible to carry out in field testing in the schools, and were presumed to give a spectrum of the students' physical capacity. The aerobic power is correlated with health outcomes (37), particularly with cardiovascular diseases (38). The level of risk of cardiovascular disease in relation to oxygen uptake has been suggested to be $35 \mathrm{ml} \mathrm{O} \cdot \mathrm{kg}^{-1} \cdot \mathrm{min}^{-1}$ for men, and $32.5 \mathrm{ml}$ $\mathrm{O}_{2} \cdot \mathrm{kg}^{-1} \cdot \min ^{-1}$ for women (37). It may be helpful in the prevention of upper and lower back pain to maintain normal joint flexibility and muscular fitness (39). Balance is one of the major facets of motor components of fitness, and is of particular importance during growth when the basic motor skills are developed, but is also of great importance in preventing falls and avoiding accidents later on in life (39).

Åstrand's cycle ergometer test and the ÅstrandRhyming nomogram $(40,41)$ with the linear relationships of work rate, heart rate and oxygen consumption, were used to estimate maximal oxygen uptake (MOU) $\left(\mathrm{ml} \mathrm{O}_{2} \cdot \mathrm{kg}^{-1} \cdot \mathrm{min}^{-1}\right)$. A correction for the age-predicted peak heart rate was made. The test person cycled on an ergometer cycle (type: Monark) for 5 min with submaximal rate of work $(600 \mathrm{kpm} / \mathrm{min}$ for girls and $900 \mathrm{kpm} / \mathrm{min}$ for boys).

Three tests of muscular strength and endurance were carried out. These were a curl-up test (42) to assess abdominal endurance, the Canadian standardised pushup test (43) to assess upper body endurance and the Sargent jump (42) to assess dynamic maximal strength in the legs. The subject performed the curl-up test lying on the back with bent knees, lifting the upper body from the ground keeping a given pace ( 25 curl-ups and downs/min). The upper body had to be lifted so high that the whole shoulder blade left the ground. The push-up test was also performed at a given pace $(25$ push-ups and downs/min) with toes touching the ground. The number of curl-ups and push-ups performed correctly was recorded as a score. The Sargent jump is a vertical jump without takeoff, with the height of the jump measured in centimetres.

Two tests of flexibility were performed, one to measure the side flexure in the spine (centimetres), and one to assess the elasticity in the hamstrings, the back of the legs (degrees) (42).
To test the dynamic balance (42), the test person stood on one foot turning the head from side to side. The time in seconds of maintained balance was registered

Body length and body weight were measured and body mass index $(\mathrm{BMI})$, weight $/ \mathrm{height}^{2}\left(\mathrm{~kg} / \mathrm{m}^{2}\right)$, was calculated. High and very low BMI-values are both related to a higher all-cause mortality rate, and to several diseases $(44,45)$.

All students were tested by the same test leader (A-C S), and performed the tests in the same succession. From the results of these seven tests a standardised index of physical capacity - a $\mathrm{z}$ score - was made for each individual. The physical index was calculated as $\Sigma\left(\mathrm{x}_{\mathrm{i}}-\overline{\mathrm{x}}_{\mathrm{i}}\right) / \mathrm{s}_{\mathrm{i}}$, where $\mathrm{i}$ was the number of the test from one to seven, $x_{i}$ was the individual's result for test number $i$, while $\bar{x}_{i}$ was the group mean, and $S_{i}$ was the standard deviation for test $i$ for girls and boys respectively. This standardised physical index was distributed around the mean 0 . A high index indicated high physical capacity for the individual, and low index low capacity. In a corresponding way, indexes were calculated for strength, MOU, flexibility and balance solely.

The third part of the study was the grades, which were received from the headmasters' offices at the schools. The grades were obtained on a 5-point scale, with 5 being the highest and 1 the lowest. The grades were to be normally distributed with 3 as a mean.

The average grade was the mean of all given grades in all the school subjects.

\section{Statistical methods}

The significance of differences in qualitative variables was tested by the chi-squared test. Student's $t$-test and Mann-Whitney's U-test were used for the comparison of quantitative variables between two groups. If there were more than two groups, the Kruskal-Wallis nonparametric test was used. Testing $\rho=0$, Pearson's cor relation coefficient, was made by using the $t$-test.

The level of significance was set to $P=0.05$. Data analyses were carried out by using SPSS (Statistical Package for the Social Sciences, Version 6.1).

The study was approved by the Committee on Ethics at the Faculty of Medicine, University of Lund (LU 88-96).

\section{Results}

The physical index was higher among pupils in theoretical education than in practical education for girls (1.51 and -1.24 respectively; $P=0.000$ ) and for boys (1.11 and -0.46 , respectively; $P=0.015$ ) (Table 2). The strength, flexibility and balance indices were higher in theoretical than in practical education for girls. Among boys the strength and balance indices 
Ann-Christin Sollerhed

\section{Sollerhed \& Ejlertsson}

Table 2. Mean (M) and confidence interval $(95 \% \mathrm{Cl})$ for physical index, strength index, MOU index, flexibility index and balance index among girls and boys in practical and theoretical education

\begin{tabular}{|c|c|c|c|c|c|c|c|}
\hline & \multicolumn{3}{|c|}{ Practical education } & \multicolumn{3}{|c|}{ Theoretical education } & \multirow[t]{2}{*}{$P$-value ${ }^{*}$} \\
\hline & $n$ & M & $95 \% \mathrm{Cl}$ & $n$ & M & $95 \% \mathrm{Cl}$ & \\
\hline \multicolumn{8}{|l|}{ Girls } \\
\hline Physical index & 66 & -1.24 & $-2.07 ;-0.42$ & 47 & 1.51 & $0.48 ; 2.53$ & 0.000 \\
\hline - Strength & 69 & -0.70 & $-1.18 ;-0.21$ & 49 & 0.95 & $0.38 ; 1.53$ & 0.000 \\
\hline- MOU & 72 & -0.03 & $-0.27 ; 0.22$ & 50 & 0.04 & $-0.22 ; 0.30$ & 0.735 \\
\hline - Flexibility & 70 & -0.32 & $-0.69 ; 0.04$ & 53 & 0.41 & $0.05 ; 0.77$ & 0.006 \\
\hline - Balance & 73 & -0.19 & $-0.41 ; 0.02$ & 54 & 0.26 & $-0.02 ; 0.54$ & 0.012 \\
\hline \multicolumn{8}{|l|}{ Boys } \\
\hline Physical index & 110 & -0.46 & $-1.16 ; 0.25$ & 47 & 1.11 & $0.07 ; 2.16$ & 0.015 \\
\hline - Strength & 110 & -0.47 & $-0.90 ;-0.05$ & 48 & 1.27 & $0.71 ; 1.83$ & 0.000 \\
\hline - MOU & 114 & 0.16 & $-0.04 ; 0.36$ & 49 & -0.37 & $-0.56 ;-0.18$ & 0.002 \\
\hline - Flexibility & 115 & -0.02 & $-0.30 ; 0.26$ & 51 & 0.04 & $-0.46 ; 0.53$ & 0.836 \\
\hline - Balance & 115 & -0.13 & $-0.29 ; 0.04$ & 51 & 0.28 & $-0.04 ; 0.60$ & 0.015 \\
\hline
\end{tabular}

* Figures are printed in bold when the difference between practical and theoretical education was significant $(P<0.05)$.

Table 3. Mean and $95 \%$ confidence interval for test results in physical tests, body weight, body height and body mass index (BMI) among girls and boys in practical and theoretical education

\begin{tabular}{|c|c|c|c|c|c|c|}
\hline & \multicolumn{3}{|c|}{ Girls } & \multicolumn{3}{|c|}{ Boys } \\
\hline & $\begin{array}{l}\text { Practical education } \\
\qquad(n=66-73)\end{array}$ & $\begin{array}{l}\text { Theoretical education } \\
\qquad(n=47-54)\end{array}$ & $P$-value ${ }^{*}$ & $\begin{array}{l}\text { Practical education } \\
(n=110-115)\end{array}$ & $\begin{array}{l}\text { Theoretical education } \\
\qquad(n=47-51)\end{array}$ & $P$-value ${ }^{*}$ \\
\hline $\operatorname{MOU}\left(\mathrm{ml} \mathrm{O}_{2} \cdot \mathrm{kg}^{-1} \cdot \mathrm{min}^{-1}\right)$ & $40.9(38.4 ; 43.4)$ & $41.6(38.9 ; 44.2)$ & 0.563 & $52.6(50.2 ; 54.9)$ & $46.5(44.3 ; 48.6)$ & 0.003 \\
\hline Push-ups (number) & $8.1(6.5 ; 9.6)$ & $12.7(10.3 ; 15.0)$ & 0.003 & $20.0(18.0 ; 22.0)$ & $25.9(23.0 ; 28.8)$ & 0.001 \\
\hline Curl-ups (number) & $19.6(17.4 ; 21.7)$ & $24.6(22.6 ; 26.6)$ & 0.002 & $23.7(22.5 ; 25.1)$ & $25.6(23.4 ; 27.7)$ & 0.036 \\
\hline Sargent jump (cm) & $30.5(28.9 ; 32.1)$ & $33.6(31.9 ; 35.4)$ & 0.011 & $44.6(42.9 ; 46.3)$ & $52.4(49.9 ; 54.9)$ & 0.000 \\
\hline Balance (s) & $47.8(38.4 ; 57.3)$ & $67.6(55.5 ; 79.7)$ & 0.010 & $45.3(37.9 ; 52.8)$ & $63.3(49.2 ; 77.5)$ & 0.095 \\
\hline Side flex. $(\mathrm{cm})$ & $20.8(19.8 ; 21.8)$ & $22.4(21.3 ; 23.4)$ & 0.026 & $22.4(21.4 ; 23.5)$ & $23.1(21.6 ; 24.6)$ & 0.202 \\
\hline Hamstring (degrees) & $88.6(85.5 ; 91.6)$ & $92.6(90.6 ; 94.6)$ & 0.044 & $88.3(86.6 ; 90.0)$ & $87.7(84.4 ; 91.0)$ & 0.716 \\
\hline Body weight (kg) & $63.2(60.3 ; 66.1)$ & $60.2(57.5 ; 62.8)$ & 0.144 & $71.4(69.3 ; 73.6)$ & $71.6(68.8 ; 74.5)$ & 0.920 \\
\hline Body height $(\mathrm{cm})$ & $164.1(162.6 ; 165.5)$ & $165.9(164.1 ; 167.7)$ & 0.110 & $177.2(175.9 ; 178.5)$ & $180.0(178.0 ; 181.9)$ & 0.023 \\
\hline BMI $\left(\mathrm{kg} / \mathrm{m}^{2}\right)$ & $23.4(22.5 ; 24.3)$ & $22.1(21.0 ; 23.2)$ & 0.082 & $22.7(22.1 ; 23.4)$ & $22.1(21.3 ; 22.9)$ & 0.275 \\
\hline
\end{tabular}

* Figures are printed in bold when the difference between practical and theoretical education is significant $(P<0.05)$.

were higher in theoretical education, but maximal oxygen uptake was lower.

The results from the physical tests are shown in Table 3 . The percentage of girls with low oxygen uptake was higher than among boys $(P=0.001)$. Among girls, $19 \%(22 \%$ in practical education and $14 \%$ in theoretical) had test results in maximal oxygen uptake below the level at which they run the risk of cardiovascular diseases $\left(32.5 \mathrm{ml} \mathrm{O} 2 \cdot \mathrm{kg}^{-1} \cdot \min ^{-1}\right)$. Among boys, $6 \%(5 \%$ in practical and $6 \%$ in theoretical education) were below the level for men $(35 \mathrm{ml}$ $\mathrm{O}_{2} \cdot \mathrm{kg}^{-1} \cdot \mathrm{min}^{-1}$.

There was a difference between the educational programmes in the study as regards the physical index (Table 4). Girls in science programmes had the highest physical index and girls in programmes for assistant nurses had the lowest index. Among boys, the highest index was found in programmes for science and the lowest in programmes for mechanics.
No differences in self-reported leisure-time exercise between practical and theoretical education could be seen. Among girls, $29 \%$ reported that they did some exercise three times or more per week, $45 \%$ once or twice per week and $26 \%$ never or seldom. Among boys, the corresponding figures were $38 \%$ three times or more per week, $27 \%$ once or twice per week and $35 \%$ never or seldom (comparison between girls and boys; $P=0.003$ ). The relation between physical index and self-reported leisure-time exercise is shown in Table 5, as well as the relation between physical index and the opinion about time allocated for physical education.

The most frequent sports activities in leisure time among boys were team sports $(39 \%)$, strength training $(28 \%)$ and jogging $(17 \%)$, and among girls aerobics $(41 \%)$, jogging $(21 \%)$, team sports $(13 \%)$ and riding $(13 \%)$.

Among girls, $15 \%$ in practical and $14 \%$ in theoreti- 
Physical capacity among adolescents

Table 4. Mean and $95 \%$ confidence interval for physicat index among girls and boys in different educational programmes

\begin{tabular}{lcc}
\hline & \multicolumn{1}{c}{ Girls } & Boys \\
\hline Theoretical programmes & & \\
$\quad$ Civics & $0.75(-0.77 ; 2.27)$ & $0.59(-1.29 ; 2.48)$ \\
Science & $2.53(1.25 ; 3.83)$ & $1.50(0.24 ; 2.76)$ \\
Practical programmes & & \\
$\quad$ Assistant nurses & $-2.08(-3.27 ;-0.88)$ & - \\
Building industry & - & $0.91(-0.15 ; 1.97)$ \\
Food industry & $-0.13(-2.62 ; 2.36)$ & $1.14(-0.76 ; 3.04)$ \\
Hairdressers & $-0.73(-2.00 ; 0.53)$ & - \\
Mechanics & - & $-2.59(-3.97 ;-1.22)$ \\
Metal industry & - & $-0.55(-1.65 ; 0.54)$ \\
\hline
\end{tabular}

Table 5. Self-reported leisure-time exercise, valuation of time allocated for physical education (PE) and physical index among girls and boys

\begin{tabular}{lrrrrrr}
\hline & \multicolumn{2}{c}{ Girls } & & \multicolumn{2}{c}{ Boys } \\
\cline { 2 - 2 } \cline { 6 - 7 } & $\begin{array}{c}\text { Physical } \\
\text { Index }\end{array}$ & & & $\begin{array}{c}\text { Physical } \\
\text { Index }\end{array}$ & $n$ \\
\hline Leisure-time exercise & & & & & \\
Never & -4.05 & 10 & & -2.58 & 8 \\
A few times per year & -0.98 & 18 & & -0.66 & 16 \\
A few times per month & 0.79 & 28 & & -0.36 & 19 \\
Regularly once a week & 1.05 & 21 & & 1.14 & 21 \\
Regularly twice a week & 0.92 & 20 & & 1.23 & 37 \\
Regularly three times a week & 1.96 & 13 & & 1.70 & 23 \\
Regularly four times or more per week & & & & & \\
Valuation of time for PE* & - & 0 & & -2.98 & 7 \\
Far too much time & -2.55 & 4 & & -2.52 & 7 \\
Somewhat too much time & -1.74 & 35 & & -1.79 & 43 \\
Just enough time & 0.13 & 41 & & 0.59 & 39 \\
Somewhat too little time & 1.83 & 30 & & 1.78 & 56 \\
Far too little time & & & & &
\end{tabular}

* For definitions, see Material and methods.

cal education thought that they got enough exercise through compulsory physical education (PE) in school to be in good condition, while $54 \%$ in practical education and $46 \%$ in theoretical education thought that the time allocated for PE was too short. The corresponding figures for boys showed that $38 \%$ in practical and $9 \%$ in theoretical education thought they got enough exercise, while $57 \%$ in practical and $72 \%$ in theoretical education thought that the time devoted to PE was insufficient. Among those who thought that the time allocated for PE was enough or too much, the mean physical index was low, and among those who thought that the time for PE was too short, the mean physical index was high (Table $5)$.

The results from questions in the questionnaire about what physical requirements future work will put on them showed that strength and aerobic fitness (oxygen uptake) were the most important physical qualities for many students $(71 \%$ and $68 \%$ respectively).

Boys in theoretical education were taller than boys in practical education. Test results from the physical tests, BMI, body weight and body height can be seen in Table 3.

A correlation was found between physical index and average grades both among boys $(r=0.22 ; P=$ $0.008)$ and among girls $(r=0.43 ; P=0.000)$.

\section{Discussion}

The results presented here show that students who attend practical programmes, which lead to occupations involving physical effort, had lower physical capacity than students in theoretical programmes, among both boys and girls. There was a difference in physical capacity already during the education of the teenagers. Higher prevalence of musculoskeletal morbidity has been found among blue-collar workers than among white-collar workers (19), and studies of back pain suggest that lower physical capacity increase the risk of being injured $(20,21)$. Lower physical capacity among students undergoing education for occupations involving physical load may place those individuals at greater risk of being injured.

Among both girls and boys in practical education, the indices for strength and balance were lower than for theoretical education. When physical demands in work are high the combination of low strength and poor balance might augment the risk of injury. Girls in this study will in the near future be occupied in medical or social services, in the food industry or working as hairdressers. All these occupations require physical effort such as lifting, doing repetitive work, standing, or walking. The boys were educated for occupations such as building, industrial work and mechanics, occupations that have been shown to have a high frequency of musculoskeletal diseases $(17,46)$.

Studies of back pain suggest that lower physical capacity may place individuals at greater risk of being injured $(20,21,42)$, while in other studies such relationships are either less convincing or absent (48). Nevertheless, high physical performance requires solid preparation, whether it is sports performance or work performance. Every sport has its special demands, as does every action in working life. As the sportsman prepares for his sport, the worker should be prepared for the work, and this is a great mission for education in school. Among girls, $22 \%$ in practical and $14 \%$ in theoretical education, had such low oxygen uptake that they were at risk of cardiovascular diseases according to Blair et al. (37). This means that the margin between ordinary work requirements and maximal capacity was small among these girls, i.e. they will find their work hard and heavy if the work requires physical load. Their preparation for physical 
Ann-Christin Sollerhed

\section{Sollerhed \& Ejlertsson}

work demands is insufficient. Other studies have shown that fitness-risk factor and activity-risk factor correlations tended to be higher in female subjects as women are less active than men $(9,36)$.

People of all ages, both male and female, benefit from regular physical activity $(21,22)$, and those adolescents who reported regular exercise during their leisure time had a high physical index in this study. Healthrelated fitness is a combination of many interacting factors, including the genetic constitution (39), and there are individual differences in the trainability, but the benefits of regular physical activity are obvious.

The BMI among girls in practical education (mean 23.4) was relatively close to the criterion for overweight for women, BMI $\geq 23.8$ (49). Physical activity has a favourable effect on fat distribution as well as overall adiposity and weight, and the strong connection between overweight and physical inactivity has been shown in several studies $(4,11,28)$. The explanation of quite high BMI among girls in practical education is probably reduced physical activity, with both less leisure-time activity and the reduction of physical education in school as contributing factors. A high BMI-value is related to a higher all-cause mortality and many diseases (44). During the 1980s the mean BMI and the prevalence of overweight and obesity increased among Swedish women, and the BMI was higher among manual workers than among those with higher education (50).

Boys in theoretical education were significantly taller than those in practical education (mean 180.0 $\mathrm{cm}$ and $177.2 \mathrm{~cm}$, respectively). The difference in body height might have both genetic and socio-economic reasons. A previous study has shown that the childhood environment was an important determinant of adult stature and health (51), and there was a detectable excess risk of morbidity and mortality from being short (52).

There was a correlation between physical index and average grades among both girls $(r=0.43)$ and boys $(r=0.22)$. Physical activity improves physical fitness $(1,2,9,36,40)$, and psychological health and mood $(6,32)$, which is important for well-being in general and to facilitate learning (3). This might explain some of the correlation between physical index and average grades. The genetic and socio-economic components cannot be ignored, of course. A major barrier to improving physical education in school is the concern on the part of administrators that spending more time in physical education takes away time from scholastic work. This concern is not justified. Even when more time is allocated for physical education, it does not result in a decline in academic performance (53). The results presented in our study show that the academic and vocational results might even improve with increased time for physical activity in the school day.
The mean physical index was high among those who thought that the time allocated for PE was too short, but low among those who thought that the time was enough or too much. Those who need physical education the most obviously do not want it

About $38 \%$ of boys and $29 \%$ of girls reported that they did some exercise three times or more per week. They thereby live up to the consensus statement for physical guidelines for adolescents, which recommends that children and adolescents should do some physical activity daily for at least $30 \mathrm{~min}$ and be engaged in vigorous exercise three times a week for at least $20 \mathrm{~min}$ at a time (54). As many pupils do not reach the weekly dose of physical activity in their leisure time, it should be a part of the school day.

The adolescents in upper secondary school are just about to leave school. If school education has any influence on health behaviour and physical capacity, the pupils are the results of the school system. Physical education has low priority in the Swedish school system. Sweden was placed number 24 among 25 countries in Europe as regards the amount of time devoted to compulsory physical education (14). The total amount of time allocated for physical education in upper secondary school is $80 \mathrm{~h}$ in practical education compared to $130 \mathrm{~h}$ in theoretical education. The fact that many children and adolescents are physically inactive during leisure time, together with the scant time allocated to physical education in school, will weaken public health considerably and augment the inequality in health between different groups. Social inequities among children and adolescents are often given special attention as they are strongly associated with unfairness as well as with possibilities for action. Equal opportunity to live a healthy life is considered by most people to be a basic human right. This basic right must include optimal motor development for all children, irrespective of socio-economic group. Health-related physical education from early childhood and through the whole school system, to develop an embodied consciousness among children, is an important step towards improvement in public health. The only way of obtaining embodied consciousness is through movement and kinaesthetic perception. The results from this study which show that physical capacity among certain groups of adolescents was low, together with the knowledge that adults' health and well-being originate in behaviour established during childhood and adolescence, strengthen the argument that increased time should be devoted to physical education.

From the 355 pupils in the 16 selected classes, all the 301 pupils $(85 \%)$ present at school on the test day answered the questionnaire, and none declined. Eight pupils did not do any physical tests at all, and a total of 270 pupils did all seven physical tests. The absence rate at school was quite normal according to the 
Physical capacity among adolescents

headmasters. The only information available about the absent group was their grades. The average grades (mean 2.6 and 3.1 for absent and present pupils, respectively) and the grades in physical education (mean 3.1 and 3.2 , respectively) were a bit lower (not significant) for the absent group than for the study group. Therefore, the results in this study might be too positive, and a slightly lower physical capacity than what was found among the adolescents might be expected.

Physical activity to improve physical capacity among children and adolescents may reduce cardiovascular diseases, prevent musculoskeletal diseases and improve health in general. It is a great challenge for parents, child care, school and society to raise the status of physical activity and physical education, and provide the opportunities for regular exercise for all children.

\section{References}

1. Malina RM. Physical activity: Relationship to growth, maturation and physical fitness. In: Bouchard C Shephard RJ, Stephens T (eds). Physical activity, fitness and health. RJ, Stephens T (eds). Physical activity,

2. Sallis JF, McKenzie TL, Alcaraz JE. Habitual physical activity and health related physical fitness in fourth-grade hildren. Am J Dis Child 1993: 147: 890-6.

3. Hannaford C. Smart moves: Why learning is not all in your head. Arlington, Vancouver: Great Ocean Publishers, 1995

4. Bar-Or O, Baranowski T. Physical activity, adiposity and obesity in adolescents. Pediatr Exerc Sci 1994: 6: 348-60.

5. Bailey DA, Martin AD. Physical activity and skeletal health in adolescents. Pediatr Exerc Sci 1994: 6: 330-47. Calfas KJ, Taylor WC. Physical activity and psychological health in adolescents. Pediatr Exerc Sci 1994: 6: 406-23.

7. Engström LM. Idrottsvanor i förändring. [Changes in exercise habits]. Stockholm: HLS Förlag, 1989.

8. Engström LM. Sports activities among young people in Sweden - trends and changes. In: Telama R, Laakso L, Pieron M, Ruoppila I, Vikho V (eds). Physical education and life-long physical activity. Jyväskylä: Foundation for promotion of physical culture and health, 1990: 11-23.

9. Pate RR, Long BJ, Heath G. Descriptive epidemiology of physical activity in adolescents. Pediatr Exerc Sci 1994: 6: $434-47$.

10. Falls HB, Pate RR. Status of physical fitness in U.S. children. In: Leppo $M$ (ed). Healthy from the start: New perspectives on childhood fitness. Washington DC. FRIC Clearinghouse on Teacher Education, 1993: 3-23.

11. Klesges RC, Shelton ML. Klesges LM. Effects of television on metabolic rate: potential implications for childhood on metabolic rate: potential implica
obesity. Pediatrics 1993: 91: 281-6.

12. Nielson AC. Nielson report on television. Chicago, IL: AC Nielsen Company, 1990.

13. Haskell WH. Physical activity, sport and health: Toward the next century. Res Q Exerc Sport 1996: 67: 37-47

14. Armstrong N, Astrand PO. Editorial. European Journal of Physical Education 1997: 2: 157-9.

15. Bongers PM, de Winter C, Kompier MAJ, Hildebrandt VH. Psychosocial factors at work and musculoskeletal disease. Scand J Work Environ Health 1993: 19: 297-312.

16. Haldeman S. North American Spine Society: failure of the pathology model to predict back pain. Spine 1991: 15: 718 24.

17. Holmström E. Musculoskeletal disorders in construction workers (Thesis). Department of Physical Therapy, University of Lund, Sweden, 1992.

18. Edén L, Ejlertsson G, Lamberger B, Leden I, Nordbeck B, Sundgren P. Immigration and socio-economy as predictors of early retirement pensions. Scand J Soc Med 1994: 3: $187-93$.

19. Andersson I, Ejlertsson G, Leden I, Rosenberg C. Chronic pain in a geographically defined general population: Studies of differences in age, gender, social class and pain localisation. Clin J Pain 1993: 9: 174-82.

20. Biering-Sörensen F. Physical measurements as risk indicators for low-back trouble over a one-year period. 198 Volvo award in Clinical Science. Spine 1984: 9: 106-19.

21. Nicolaisen N, Jörgenson K. Trunk strength, back muscle endurance and low-back trouble. Scand J Rehab Med 1985: 17: $121-7$

22. Pate RR, Pratt M, Blair SN, et al. Physical activity and public health. A recommendation from the Centers for Disease Control and Prevention and the American College of Sports Medicine. JAMA 1995: 273; 402-9.

23. Astrand PO. Why Exercise? Med Sci Sports Exerc 1992 24: 153-62.

24. Blair SN, Kampert JB, Kohl HW, et al. Influences of car diorespiratory fitness and other precursors on cardiovascular disease and all-cause mortality in men and women. JAMA 1996: 276: 205-10.

25. Haskell WL, Leon AS, Caspersen CJ, et al. Cardiovascular benefits and assessment of physical activity and physical fitness in adults. Med Sci Sports Exerc 1992: 24: 201-20.

26. Shinton R, Sagar G. Lifelong exercise and stroke. Br Med J 1993: 307: 231-4

27. Tipton CM. Exercise, training and hypertension: An update. Exerc and Sports Sci Rev 1991: 19: 447-505.

28. DiPietro L. Physical activity, body weight and adiposity: An epidemiologic perspective. Exerc Sport Sci Rev 1995: 23: $275-303$.

29. Kriska AM, Blair SN, Pereira MA. The potential role of physical activity in the prevention of non-insulin-dependent diabetes mellitus: The epidemiological evidence. Exerc Sport Sci Rev 1994: 22: 121-43.

30. Snow-Harter C, Marcus R. Exercise, bone mineral density and osteoporosis. Exerc Sport Sci Rev 1991: 19:351-88.

31. Lee I-M. Physical activity, fitness and cancer. In: Bouchard C. Shephard RJ, Stevens T (eds). Physical activity, fitness and health: international proceedings and consensus statement. Champaign IL: Human Kinetics, 1995: 814-31.

32. Pfaffenbarger RS, Lee IM, Leung R. Physical activity and personal characteristics associated with depression and suicide in American college men. Acta Psychiatr Scand 1994: 377: 16-22.

33. Bouchard C, Shephard R, Stephens T. Physical activity, fitness and health: International proceedings and consensus statement. Champaign IL: Human Kinetics, 1994.

34. Armstrong N, Simons-Morton B. Physical activity and blood lipids in adolescents. Pediatr Exerc Sci 1994: 6: 381405

35. Cresanta JL, Burke GL, Downey AM, Freedman DS, Berenson GS. Prevention of atherosclerosis in childhood: Prevention in primary care. Pediatr Clin North Am 1986: 33 $835-58$

36. Sallis JF, Patterson TL, Buono MJ, Nader PR. Relation of cardiovascular fitness and physical activity to cardiovascular disease risk factors in children and adults. Am J Epidemiol 1988: 127: 933-41

37. Blair SN, Kohl HW, Pfaffenbarger RS, Clark DG, Coope KH, Gibbons LW. Physical fitness and all-cause mortality. 


\section{Ann-Christin Sollerhed}

\section{Sollerhed \& Ejlertsson}

A prospective study of healthy men and women. JAMA 1989: 262: $2395-401$.

38. Haskell WL. Physical activity in the prevention and management of coronary heart disease. Physical Activity and Fitness Research 1995: Series 2: 1-7.

39 Bouchard C. Shephard RJ. Physical activity, fitness and health. The model and key concepts. In: Bouchard $\mathrm{C}$ Shealth. The RI, Stephens T (eds) Physical activity fitness Shephard RJ, Stephens T (eds). Physical activity fitnes and health: International proceedings and consensus state-

40. Åstrand PO, Rodahl K. Textbook of work physiology. New York: McGraw-Hill, 1986.

41. Åstrand PO, Ryhming I. A nomogram for calculation of aerobic capacity from pulse rate during submaximal work J Appl Physiol 1954: 7: 218-21

42. Bergqvist $M$, Hedberg $G$, Rahm $M$. Utvärdering av tes för bedömning av styrka, rörlighet och koordination. [Evaluation of tests for assessment of strength, flexibility and coordination]. Stockholm: The Swedish National Institute of Occupational Health. Arbete och Hälsa, 1992. 5.

43. Golding L Mayers C Sinning W Y's way to physical fitness. Champaign IL: Human Kinctics, 1989

44. VanItallie TB, Abraham S. Some hazards of obesity and its treatment. In: Hirsch J, VanItallie TB (eds). Recent adits treatment. In: Hirsch J, Vanltallie TB (eds). Recent ad$1-19$.

45. National Research Council. Diet and health. Implications for reducing chronic disease risk. Washington DC: National Academy Press, 1989: 563-92.

46. Vingård E, Alfredsson L, Fellenius E, Hogsted C. Disability pensions due to musculoskeletal disorders among men in heavy occupations. Scand J Soc Med 1992: 20: 31-6.
47. Åstrand NE, Isacsson SO. Back pain, back abnormalities, and competing, psychological, and social factors as predictors of sick leave, early retirement, unemployment, labour turnover and mortality: a 22 year follow up of male employees in a Swedish pulp and paper company. Br J Ind Med 1988: 45: 387-95.

48. Battié MC. The reliability of physical factors as predictors of the occurrence of back pain reports. A prospective study within industry. Göteborg. Sweden: University of Göteborg. 1989 .
withy. Goteborg, Sweden: University of Gote-

49. Joint $\mathrm{FAO} / \mathrm{WHO} / \mathrm{UNU}$ expert consultation. Energy and protein requirements. Technical Report Series No. 724. Geneva: WHO, 198

50. Kuskowska-Wolk A, Bergström R. Trends in body mass index and prevalence of obesity in Swedish women 1980 89. J Epidemiol Community Health 1993: 47: 195-9.

51. Nyström-Peck $M$, Vågerö $\mathrm{DH}$. Adult body height and childhood socioeconomic group in the Swedish population. J Epidemiol Community Health 1987: 41: 333-7.

52. Nyström-Peck M, Vågerö DH. Adult body height, selfperceived health and mortality in the Swedish population. J Epidemiol Community Health 1989: 43: 380-4.

53. Shephard RJ, Lavallee H, Volle M, LaBarre R, Beaucage C A ademic skills and required physical education: The Che Trols Rivieres experience. Supplement 1994: 1: $1-12$.

54. Sallis JF, Patrick K. Physical activity guidelines for adolesents: Consensus statement. Pediatr Exerc Sci 1994: 6: 302- 